\section{Professional education in the field of injury prevention}

\author{
Roderick J McClure
}

One of the defining characteristics of a profession is that its members take responsibility for enabling, educating and training emerging professionals in their field. This education role goes hand-in-hand with a profession's responsibility to monitor members' adherence to ethical, technical and professional standards.

In the field of injury prevention, there are many who have incorporated this service role into their professional DNA. We can all identify mentors whose passion for educating future injury prevention researchers and practitioners seems to have grown as their experience and opportunity to contribute does too.

Yet surprisingly, there are very few opportunities for injury education enthusiasts to share their teaching methodologies and approaches for other educators to learn from. There are few platforms, either for written text or verbal exchange, that document pedagogies, curricula and innovative achievements in a way that facilities academic development. Where is the body of knowledge we can use to inform budding professionals and help them make sense of their new professional life?

We all tend to see things from our own perspective. At one end of the injury academic contimuum is the lay view that injury prevention is simply common

Correspondence to Dr Roderick J McClure, School of Rural Medicine, University of New England, Armidale, NSW 2351, Australia; rmcclure@une.edu.au sense. At the other are the researchers who view injury prevention as high science. Somewhere in the middle are those who focus on the translation of the science to practice, and back again. How do we balance the seasaw with regards to our educational responsibilities? What do we teach our students? Do we measure up as professional educators or do we expect next generations to learn injury prevention, using an apprenticeship model, by watching us do what we are currently focused on doing?

I suspect most readers of the journal would say that, as educators, we are doing a pretty good job. Injury prevention is well established in the public health curricula of universities throughout the world. Many authors of manuscripts published in the journal will be teaching injury prevention, either formally or informally, on an ongoing basis. Most of us would have clear ideas about how injury prevention is best learnt.

However, all of us would appreciate a clear, documented, developing discussion about the academic frameworks that support advancement in injury prevention learning. For this reason, in this issue, injury prevention is launching a new category of manuscript that we hope to publish regularly under the header 'Education'.

Our launch manuscript 'An Injury Prevention Class Exercise-threepronged list making' is authored by David Hemenway. ${ }^{1} \mathrm{He}$ opens with the point on which this editorial depends: 'It is difficult to find classroom exercises that have been specifically designed for injury prevention students'. My thanks to Professor Hemenway for his insight in picking the gap. Many thanks for his example, which is a challenge both to his students and to us all.

What is the core curriculum of injury prevention science? How do we teach it? Why do we teach it this way? What teaching methodologies are we actually using when we do what we do? Is our approach the best way to support student learning? How effective are our efforts? Is our pedagogy as evidence-based as our injury prevention practice?

I look forward to your responses. Over time, these pages will document the science of professional education in our field.

Funding The authors have not declared a specific grant for this research from any funding agency in the public, commercial or not-for-profit sectors.

Competing interests None declared.

Patient consent for publication Not required.

Provenance and peer review Not commissioned; internally peer reviewed.

(C) Author(s) (or their employer(s)) 2019. No commercial re-use. See rights and permissions. Published by BMJ.

$$
\text { Check for updates }
$$

To cite McClure RJ. Inj Prev 2019;25:479.

Inj Prev 2019;25:479.

doi:10.1136/injuryprev-2019-043554

ORCID iD

Roderick J McClure http://orcid.org/0000-0002-90678282

\section{REFERENCE}

1 Hemenway D. Injury prevention class exercise: threepronged list making. Inj Prev 2019;25:565-9. 